\title{
Purification Strategy in the Arabic Translations of Diary of A Wimpy Kid
}

https://doi.org/10.33806/ijaes2000.20.1.10

\author{
Hanan Al-Jabri \\ The University of Jordan, Jordan
}

\begin{abstract}
Diary of a Wimpy Kid is a highly regarded series of novels and the winner of many prizes worldwide targeting children and teenagers. The current paper aims to compare the original novel written in English with its Arabic Translation to highlight the purifying measures taken by the publishers to adapt the inappropriate or unsuitable content for the target reader. The original novel includes mentions of love, relationships, indecent clothes, religion and cultural holidays which were all altered and adapted to the Arabic culture. Based on an interview conducted with the publishers of the Arabic translation, translating and writing for children go through a strict filter to guarantee that any content corresponds with Arabic values to guarantee the book's access to every Arab country. The translator, therefore, seems to be free from the blame of making the changes to the original novel as the publishers dictated the translation guidelines. The paper shows that the translators resorted to using strategies such as omission, substitution, and cultural adaptations to purify the content of the original novel.
\end{abstract}

Keywords: Children's literature, translation, purified content, cultural adaptation, translation strategies.

\section{Introduction}

Children's literature differs from adults' literature in many aspects including themes, languages, and plot. In the Arab World, however, more special requirements which are related to the norms and values imposed by Arab societies come into play when writing and translating for children. Taboo topics and modern themes which may be accepted and considered normal in the West are still rejected in the Arab World by publishers, parents and many people who view literature as a source of education and moral values. The same reservations and requirements which control writing for children apply also to the translated 
literature directed to children. Themes, characters, scenes and language which are not suitable for children are normally censored or adapted to make the text more appropriate to the Arab culture and, thus, accepted to enter the many Arab countries. Interestingly, same measures, according to Al-Qinai (2005), are sometimes applied to translate literature for adult readers in the Arab World to meet the expectations of the Arab society. While these measures are beyond the scope of the current paper, it would be interesting to study them in future research.

This paper aims at pointing out some examples of changes made to the source text (ST), Diary of a Wimpy Kid, in order to make the text more suitable for Arab children. Diary of a Wimpy Kid is a satirical novel for children and teenagers written and illustrated by Jeff Kinney. The book comprises twelve novels each of which is narrated by a boy named Greg who writes his diaries about his struggles to fit in middle school. Since its release in 2004, the book received great attention from readers around the world as well as many awards and prizes and, therefore, was translated to many different languages including Arabic. The Arabic translations of the series were published starting from 2011 by Arab Scientific Publishers, Inc. under the title مذكراتطالب (Diary of a Student). During an interview conducted by the researcher with Mr. Bassam Chebaro, a publisher in the aforementioned publishing company, he stated that two translators were responsible for the translation of the English novels into Arabic. However, according to him, little freedom was given to them as the publishers were the ones responsible for setting the guidelines for the translation process. Cultural values and religious beliefs were two main factors taken into account when dictating these guidelines according to Mr.Chebaro.

A close comparison between the original series and the Arabic versions shows that the latter follow a colour code similar to the original. The cover of the Arabic books match the English ones in almost every detail. The name of the author is written in Arabic in a clear manner along with the Arabic publishing company. However, the Arabic translation of the main title of the novels seems different. It reads مذكراتطالب(Diary of a Student), rather than the English one (Diary of a Wimpy Kid). The choice of such a title may be attributed to marketing purposes as the novel targets school students in particular. The Arabic cover states clearly that the audience targeted by this book is six graders (11-12 years olds). The English book, on the other hand, does not indicate a specific age group although it is believed to be suitable for children as well as teenagers. Mr.Chebaro maintained that the age alert on the Arabic book was agreed upon in the 
publishing company as a routine policy when publishing for children.

This paper is an attempt to compare the original book with its Arabic translations to underpin content which was purified in the Arabic translations to make the text more culturally appropriate. The paper will particularly examine five categories deemed taboos in the Arabic culture, especially when addressed to children. These categories are love and relationships, religion and God, national food and holidays, indecent clothes, and rude language. This book was chosen due to its popularity among Arab schoolers and due to the culturally sensitive elements it involves.

\section{2- Children's literature: Special rules}

Children's literature has always sparked controversy among scholars and critics due to its complex nature. In her essay "Essentials: What is Children's Literature? What is Childhood?" KarínLesnik-Oberstein (1999) raises important questions regarding children's literature including how it is supposed to be defined and the factors which come into play when trying to define it. Some of these factors are deciding whether children's literature is what is written by children or written for children. If written for children, what about adults who read them? And what about adult books which are also read by children?

However, some scholars, such as Hunt (2001:32), focused only on the reader maintaining that children's literature is "defined in terms of the reader rather than the author's intentions or the texts themselves." According to Hunt's definition, children's literature can include books written originally for adults but read occasionally by children. In the same vein, Oittinen (2000:61) defines children's literature as "literature produced and intended for children or as literature read by children", which, therefore, includes any book read by or found interesting by children including adult books.

Therefore, children's literature can mean anything read by children or intended for children. However, children's literature, unlike adults' literature, fulfils multi-functions; while one expects adult books to entertain them as a sole purpose sometimes, children books exceed the entertainment purpose to the educational one.According to Nikolajeva (1996:3), literature targeting children "has from the very beginning been related to pedagogics" and has always been considered "a powerful means for educating children". This view of literature as a source of education, which is probably decreasing in the Western societies, is still very much alive in the Arab societies. Children's literature is basically meant to 
teach children, to remind them of the dichotomy between good and evil, a process which, according to Puurtinen (1995:17), affects both the process of writing for children and translating for them. This view would probably have much power over the choice of themes, characters, and language in any book meant for children, let alone translating for them.

\section{3- Translating children's literature in the Arab World}

O'Connell (2006:23) defines translation as:

A cultural activity that is conducted according to certain norms which are didactic, ethical, and religious. They determine what is translated, when and where, and they change continually. The norms may vary from one language to language, culture to culture and generation to generation. While specific norms exist in all cultures for writing and translation of children's literature, it does not follow that the same approach is adopted in the case of any two languages.

Although one may think that translators are the actual decision makers responsible for their translated works, they hardly are, especially when these works are related to children. People involved in the translation for children, such as publishers, have normally the say over all aspects of children's book, such as the motifs, themes, and the cover among others. Munday (2008:143) maintains that publishers and editors "choose the works and commission the translations, pay the translators and often dictate the translation method". When translating children's literature, the translator seems to be advised by editors and publishers to make appropriate changes to the source text to make it suitable for the target culture. In the same vein, Alvstad (2003:268) maintains that it is publishers who are responsible for all translation decisions including decisions to keep or omit the illustrations from the source text, change the translator's text and publish the book in a series.

The publishers of the book under discussion have also stated that the two anonymous translators of the novel had hardly any control over the translation decisions made in the novel. This reveals that translating and writing for children are governed by institutional regulations rather than individual opinions. Stolze (2003:209) argues that when translating for children, the original content is already adapted to suit the children's world of thoughts to meet the expectations of society. 
However, different societies have different rules with regard to what is acceptable and what is not. Therefore, two principles were suggested by Shavit (1986:112-113) which should govern the process of translation for children. These principles are: "1). Adjusting the text in order to make it appropriate and useful to the child, in accordance with what society thinks is 'good for the child.'2). Adjusting plot, characterization and language to the child's level of comprehension and his reading abilities". These two principles are almost universal; however, the degree of change and adaption differs according to how much every society seems to accept or reject certain themes and ideas.

In the Arab World, the complexity of writing and translating for children is probably more prominent. Morality and ideology are still dominating many aspects in societies, and children's literature is no exception. Because religion, cultural values, and societal expectations govern societies in almost every aspect, Western themes, such as violence, racism, and sexism, have almost no room to be transferred into the Arab culture through translation. Such themes are believed to cause harm more than good, especially at such a tender age. According to Yousef (2002:109), "third-world countries are seen as trying to preserve their indigenous cultures and to put up tough resistance to any form of cultural invasion."

Ahmad (2006) claims that literature can influence the way children think. It can shape their identity and build their experiences. Therefore, it is obligatory to guarantee that books meant for children correspond with what they are familiar with by eliminating any negative influence. It is important to preserve children cultural identity which is, according to Yousef (2019:71), "the feeling of belonging to a certain social or cultural group". Similarly, Ad-Deek (2001) emphasises the necessity to purify the content of translated texts from any harmful intentions that might encourage theft, violence and stupid adventures. According to Manaa (2001), $75 \%$ of the books translated for children into Arabic have "harmful" themes. Such scholars view translation as a possible harmful method that can jeopardise the Arab generations. Youssef (1985: 20), for example, argues that translating books from the West is a cultural invasion which threatens Arab children. Therefore, purifying the content of these book is probably viewed as a moral obligation to preserve the Arab identity. Therefore, adults including publishers, parents, educators, academics and critics filter what needs to be translated so as to fit into the society's norms and expectations. 


\section{4- Purification strategy to purified content}

Although the Arab world is a combination of various cultures which have different levels of democracy and freedom, there are some themes that would not be accepted by any Arab country including drug addiction, homosexuality, masturbation, menstruation, secret love or juvenile pregnancy. Therefore, these topics, according to Mdallel (2004), are excluded from the scope of literature because it is believed that "talking openly about such problems is far more harmful than beneficial" and children should be "spared such problems".

Therefore, purification is a strategy adopted in translation to adapt the text to the values of the parents or teachers (Klingberg 1986:90-91). Events and objects considered unsuitable, such as ideological, religious, or frightening things, are purified or censored. Klingberg(1986:58) claims that the "aim [of purifications] is to get the target text in correspondence with the set of values of its readers - or rather in correspondence with the supposed set of values of those who feel themselves responsible for the upbringing of the intended readers: parents, teachers, librarians, critics".

In fact, the strategy of purification goes hand in hand with concepts proposed by other scholars such as the theory of managing (Farghal 1993) and domestication (Venuti 1995). By adopting a domestication approach, the translator tries to minimize the strangeness of the foreign text to accommodate the cultural values of the target language readers (Venuti 1995:20). Similarly, managing the text, according to Farghal (1993), involves the translator's ideological superimposition on the TL text aiming to gear the TL text's message toward meeting his own goals.

The present paper adopts the view of (Piechurska-Kuciel and SzymanskaCzaplak 2013:22) who considerpurification strategy as a strategy "which aims at removing all content considered inappropriate or unsuitable for the Arab reader." As explained earlier, Arab societies do not accept many Western themes and values which are considered a threat to their identity. Therefore, censorship is needed to purify content and make it suitable especially for children.

\section{Analysis}

To achieve its goal, the paper will adopt a descriptive approach in analysing the content of the source and target texts. A comparative approach will also be used to make comparison of the ST and TT excerpts to show the possible strategies which 
the translators applied to adapt the content of the ST. The analysis will be based on five categories under which different examples in the original English, the target Arabic and back translation (BT) will be presented in a table. The sections are based on the categories which are considered sensitive in the Arab culture including Love and relationships, religion and God, cultural food and holidays, indecent clothes, and rude language. Following every table, a discussion will take place to explain the strategies used to achieve purified content. The first category is love and relationships.

\subsection{Love and relationships}

Table 1 below illustrates some of the most outstanding examples of love expressions in the original novel and their Arabic translations.

Table 1: Examples of expressions related love and relationship

\begin{tabular}{|c|c|c|}
\hline English & Arabic & $\begin{array}{c}\text { Back } \\
\text { translatio } \\
\mathbf{n}\end{array}$ \\
\hline $\begin{array}{l}\text { (1) Kiss me, Rex. Kiss me to } \\
\text { help me snap out of my } \\
\text { amnesia }\end{array}$ & ساعدنيريكس، ساعدنيعلساستعادةذاكرتي & $\begin{array}{l}\text { Help me } \\
\text { Rex snap } \\
\text { out of my } \\
\text { amnesia }\end{array}$ \\
\hline $\begin{array}{l}\text { (2) Then I guess you'll have } \\
\text { to kiss both of us! }\end{array}$ & إذأَظنأنهعليكأنتعانقنانحنالاثنتين & $\begin{array}{l}\text { I think you } \\
\text { should hug } \\
\text { us both }\end{array}$ \\
\hline$\frac{\vdots \text { KISS: }}{\text { (3) }}$ & & $\begin{array}{l}\text { Photo } \\
\text { shows } \\
\text { omission of } \\
\text { caption } \\
\text { and } \\
\text { adaptation } \\
\text { of kiss }\end{array}$ \\
\hline $\begin{array}{l}\text { (4) HAPPY NINE-AND-A- } \\
\text { HALF-DAY } \\
\text { ANNIVERSARY! }\end{array}$ & نحنصديقانمنذتسعة أيامونصف! & $\begin{array}{l}\text { We are } \\
\text { friends for } \\
9 \text { days and } \\
\text { a half }\end{array}$ \\
\hline
\end{tabular}




\begin{tabular}{|c|c|c|}
\hline (5) Boyfriend Trouble & مشاكلالصداقة & $\begin{array}{l}\text { Friendship } \\
\text { troubles }\end{array}$ \\
\hline $\begin{array}{l}\text { (6) And I'm sorry I kissed } \\
\text { Justin at the roller rink }\end{array}$ & وأناآسفةلأننيصرختفيوجهكورغبتفيإثارةغيرت & $\begin{array}{l}\text { I'm sorry I } \\
\text { yelled at } \\
\text { you and } \\
\text { wanted to } \\
\text { make you } \\
\text { jealous }\end{array}$ \\
\hline $\begin{array}{l}\text { (7) Cutest Couple } \\
\text { Rowley \& Abigail }\end{array}$ & روليوأبيغيل & $\begin{array}{l}\text { Best } \\
\text { friends } \\
\text { Rowley \& } \\
\text { Abigail }\end{array}$ \\
\hline
\end{tabular}

In the above examples, purification strategy can be observed where the translator adapted inappropriate content related to love relationships to suit the target culture which does not approve such relationships, especially among children and teenagers. Different strategies were applied by the translator to achieve purification. For example, omission can be seen in example 1 where Kiss me (قبتلن was omitted and not delivered at all. Moreover, the illustration, in example 3, has gone through a filter process where the caption kiss smooch was omitted altogether and the characters are shown sitting next to each other innocently instead of kissing each other. Another strategy that can be detected in the previous examples is substitution. The translator, for example, replaced kiss both of us in example 2 with(تعانقا)hug us where the hug bears less intimacy and more innocence. Also, mentions of boyfriend, anniversary and couple were replaced with concepts of friendship which tones down the intimacy of the original.

The translated book seems to avoid any mentions of love probably to meet the expectations of the Arab society which deems any love relationship, especially among teenagers, a taboo. Suleiman (2005) notices that there is strict observance of children's taboos, including avoidance of alcohol (or its replacement by other non-alcoholic drinks), prohibited foods (or replacement by other permitted foods, e.g. lamb or chicken instead of pork), violence, death, bad manners, sex, teenage relationships, bodily functions, weaknesses and faults of adults.

However, the original novel invested the love story between the two teenagers (Rowley \& Abigail) as a source of satire to show how the friendship between the protagonist (Greg) and his friend (Rowley) was negatively affected by the latter's love relationship with Abigail. This investment seems lost in the 
Arabic text which shows this relationship as innocent friendship instead of love.

\subsection{Religion and God}

Table 2 below demonstrates examples related to religion and God in the original text and their counterparts in the Arabic text.

Table 2:Examples of expressions related to religion and God

\begin{tabular}{|c|l|l|}
\hline English & \multicolumn{1}{|c|}{ Arabic } & Back translation \\
\hline $\begin{array}{l}\text { (1) Daddy, is rain just God } \\
\text { sweating? }\end{array}$ & $\begin{array}{l}\text { Daddy, is this } \\
\text { running water rain? }\end{array}$ \\
\hline $\begin{array}{l}\text { (2) I think she has a direct } \\
\text { pipeline to God or } \\
\text { something. }\end{array}$ & No translation & \\
\hline (3) Jesus in Disguise & المطنيارئ & The disguised \\
\hline
\end{tabular}

Similar to love and relationships, jokes involving God are not acceptable in the Arab society where religion is sacred and respected. These jokes can even be a punishable crime in some countries. The three examples mentioned above show how comfortable the Western society is talking and even joking about God. Translating these examples in Arabic would not have gone smoothly. In fact, they would not have been approved by censorship authorities in the first place. Therefore, omission can be seen in most examples. The publishers, who were interviewed by the researcher, maintained that to guarantee access to every country in the Arab World, careful purification measures were applied to the content of the original, especially when related to religion. Moreover, the publishers explained that they bear a moral responsibility for the Arab children which required them to stop any attempts to distort their beliefs and values. Therefore, moral responsibility and marketing purposes can be considered the main reason behind such changes to the original novel.

\subsection{Cultural food and holidays}

Examples of cultural food and holidays in the original text and their Arabic counterparts are demonstrated in the following table.

Table 3:Examples of expressions related to culture and holidays

\begin{tabular}{|c|c|c|}
\hline English & Arabic & Back translation \\
\hline
\end{tabular}




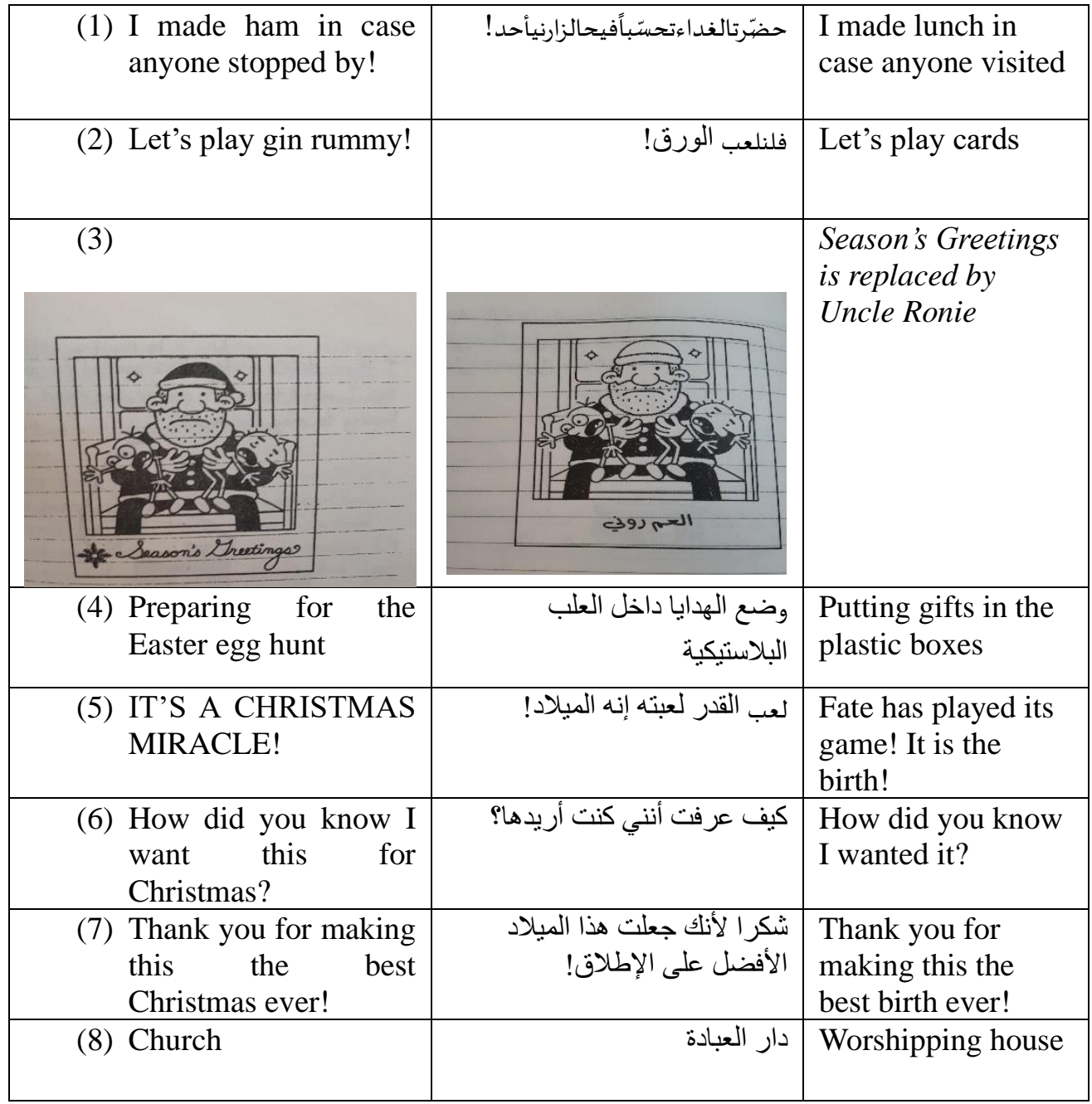

Although Christianity is one of the widely practised and respected religions in the Arab society, the translated text seems to avoid mentioning any links to it. For example, the translators, advised by the publishers, replaced Christmas using the general, yet vague word الميلاد the birth. The Arabic word is normally used in reference to people's birthdays while عيد الميلاد is the phrase used normally to refer to Christmas. Therefore, the Arabic text seems to refer to a personal occasion rather than a cultural one. Moreover, the picture of Santa Clause with the caption Season's Greetings was replaced by a picture of a man with the caption العمروني uncleRonie giving the impression that the picture is of a random person rather than of Santa. In other examples such as 5 and 6, Christmas was omitted altogether. 
Similarly, Easter related words were not translated. Easter eggs in example 4 was replaced by the general word الهاداياgifts, which carries no cultural associations. The last example is also interesting as Church was rendered using the general phrase دار العبادة (worshipping house) which can mean any place for practising religion including mosques. The Arab world has many Christians and churches. However, some countries do not. According to the publishers, the aim was for the translated novel to reach every Arab country in the Arab World. Therefore, it seems that extreme purification measures were taken to guarantee access to all Arab countries including the more conservative ones.

\subsection{Rude language}

Table 4 shows some examples of rude language in the original text and their translations in the Arabic novel.

Table 4:Examples related to rude language

\begin{tabular}{|c|c|c|}
\hline English & Arabic & Back translation \\
\hline $\begin{array}{l}\text { (1) Happy birthday } \\
\text { poopsie! }\end{array}$ & ذكرى ميلاد سعيدة بو بسي! & Happy birthday poopsie! \\
\hline $\begin{array}{l}\text { (2) Girls are stinky } \\
\text { poos! }\end{array}$ & الفتيات مقرفات! & Girls are disgusting \\
\hline $\begin{array}{l}\text { (3) Rodrick, I want } \\
\text { your dirty } \\
\text { underwear off the } \\
\text { kitchen table } \\
\text { before I get home } \\
\text { from work. }\end{array}$ & 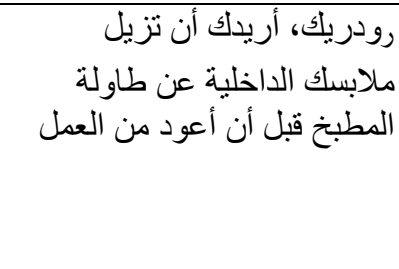 & $\begin{array}{l}\text { Rodrick, I want your } \\
\text { underwear off the } \\
\text { kitchen table before I get } \\
\text { home from work. }\end{array}$ \\
\hline $\begin{array}{l}\text { (4) Hey, Mr Ira, } \\
\text { You pooped your } \\
\text { pants again. } \\
\text { Stink lines (from the } \\
\text { poop) }\end{array}$ & أخرى جون. كريد، لقد اتسخ بنطالك مرة & $\begin{array}{l}\text { Hey, Mr Ira, } \\
\text { Your pants got dirty } \\
\text { again. } \\
\text { Stink lines (from the } \\
\text { dirt) }\end{array}$ \\
\hline (5) Mama, I'm peeing! & ماما، أريد الذهاب إلى & $\begin{array}{l}\text { Mama I want to go to } \\
\text { the toilet }\end{array}$ \\
\hline
\end{tabular}

The examples in the above table show how keen the translators were to purify the original language by replacing rude or vulgar words with more polite choices. Instead of poos, example 2, and poop, example 4, the translators opted for more general and much more formal words in Arabic (مقرفات) disgusting; 
dirt. Similarly, the verb peeing in English was replaced with a highly formal word المرحاضtoilet which no child uses in everyday language. Omission can also be observed in example 3, where the adjective dirty describing the underwear, was omitted. The same explanation probably applies here; the publishers view their task as educational especially when related to children. The language must be as polite as possible even if the context demands otherwise.

Therefore, strategies such as omission and substitution were used to achieve the purified content.

\subsection{Indecent clothes}

Illustrations which show indecent clothes from the original novel are included in Table 5 below along with their Arabic counterparts.

Table 5:Examples related to indecent clothes

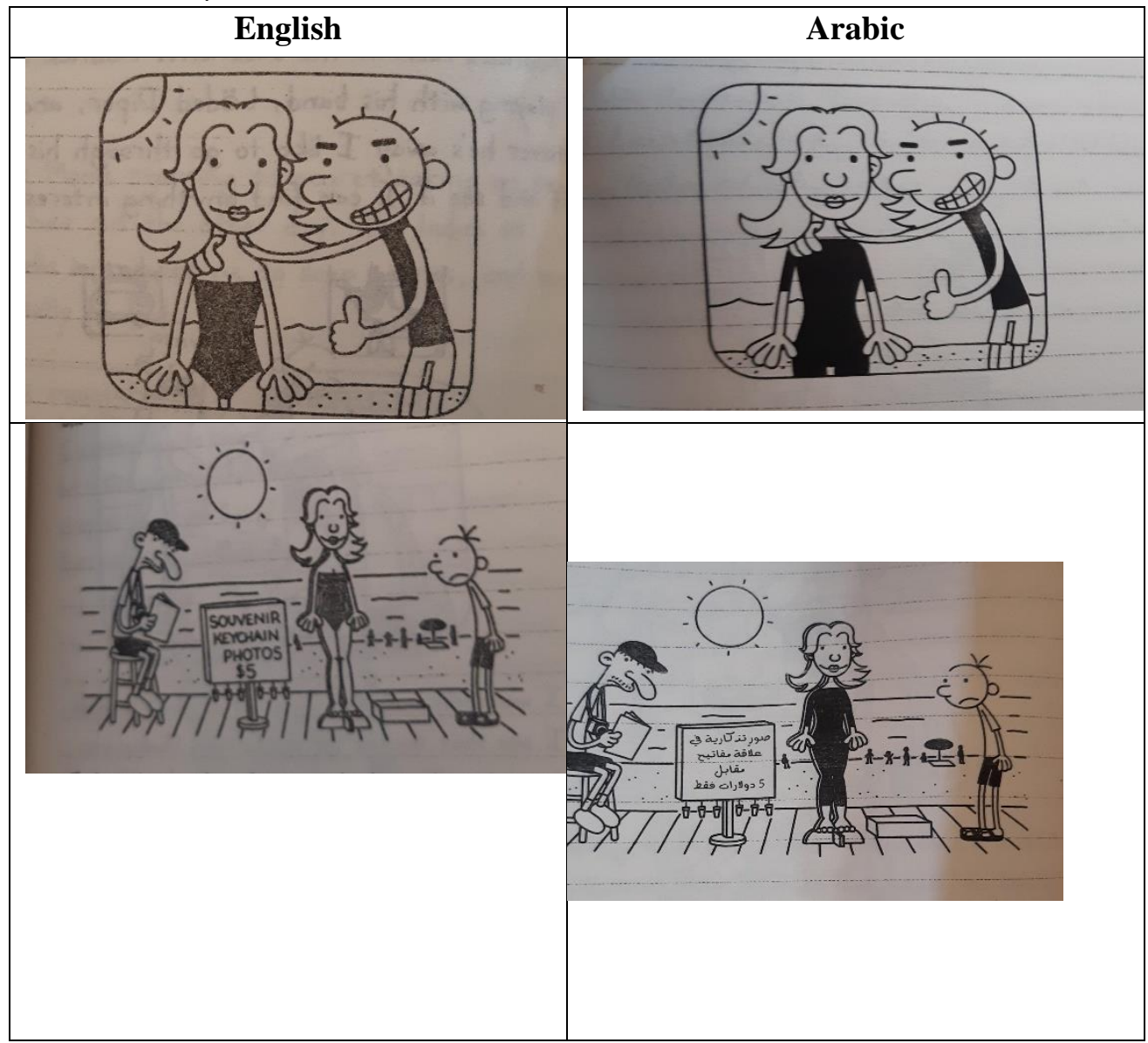




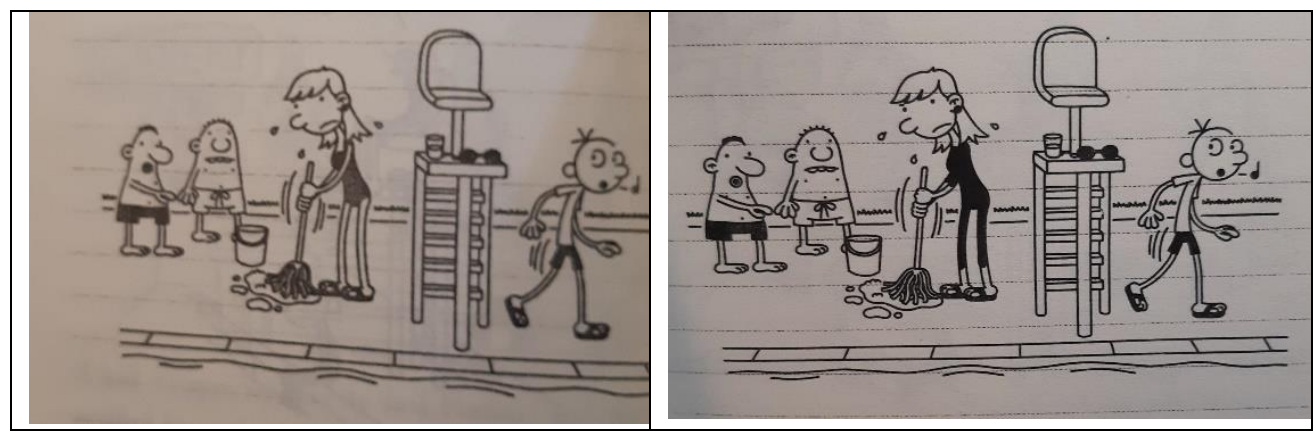

Illustrations, which are many in the novel, have undergone similar purification process. The images of women in bathing suits were all replaced with "modest" versions. According to the publishers, the Arabic novel was aimed to reach every single Arab country including the more conservative ones. For this reason, measures such as covering up semi nude women seem to have been taken.

\section{Conclusion}

To conclude, the translation process for children in the Arab world seems governed by the values and expectations of the Arab society. Children's literature is not only a source of entertainment but of education as well. Therefore, publishers of children's books, whether written originally in Arabic or translated from other languages, monitor the content of these books and purify their content if needed. The fact that the Arab World includes countries with different levels of liberation makes it compelling to purify any content that might be rejected by any Arab country to guarantee the book's access to every Arab country. Therefore, mentions of love, relationships, religions other than Islam, indecent clothes and rude language, were among the categories which were purified in the process of translation. To achieve this goal, several translation strategies seem to have been used by the translators including omission and substitution. 
Hanan Al-Jabri

The University of Jordan, Jordan

Email: hanan_aljabri@outlook.com

\section{References}

Ad-Deek, Nadi. (2001) Adab at-Tifl: DirasaNaqdiyyaTatbiqiyya min as-

Sumariyinhatta al-Qarn al-'Ashrin) (Children's Literature: A Practical Critical Analysis from Sumerians to 20th Century). 'Aka': Mu'ssasa alAswar.

Ahmad, Samir. (2006). Adab al-Atfal: Qira'atNazariyyawaNamazijTatbiqiyya (Children's Literature: Theoretical Readings and Practical Examples). Oman: Dar al-Masiralil-Nashrwa at-Tawzi'.

Al-Quinal, Jamal. (2005). 'Manipulation and censorship in translated texts'.

http://www.aieti.eu/pubs/actas/II/AIETI_2_JQ_Manipulation._pdf (Retrieved on 24th February 2019).

The rest of the entries should follow the above indentation and the Author's Guide of the journal....

Alvstad, Cecilia. (2003). 'Publishing strategies of translated children's literature in Argentina: A combined approach.' Meta: Translators' Journal, 48: 266-275.

Farghal, Mohammed. (1993) 'Managing in translation: A theoretical model', Meta:Translators' Journal, 38: 257-267.

Gentzler, Edwin. and Maria Tymoczko(2002). 'Introduction'.In Edwin Gentzler and Maria Tymoczko (eds.), Translation and Power, xi-xxiiii. Amherst: University of Massachussets Press.

Hunt, Peter. (2001). Children's Literature. Malden, Massachusetts: Blackwell Publishers.

Klingberg, G. (1986). Children's Fiction in the Hands of the Translators. Malmö: Libervörlag. 
Lesnik-Oberstein, Karin. (1999). 'Essentials: What is children's literature? What is childhood?' In Peter Hunt (ed.), Understanding Children's Literature, 14-29. London: Routledge.

Manaa, Aziza.(2001). 'al-Adab al-Mutarjam li-Tifl: dirasatahlilialil-Madhmun attarbawi. Translated literature for children: An analyticalstudy of the educationalcontent'. Arab Journal of Education, 21 (2): 201-226.

Mdallel, Sabeur. (2003). 'Translatingchildren's literature in the Arab World: The state of the art'. Meta Translators' Journal, 48 (1): 298-306.

Munday, Jeremy. (2008) Introducing Translation Studies: Theories and Applications.London and New York: Routledge.

Nikolajeva, Maria. (1996). Children's Literature Comes of Age: Toward a New Aesthetic. New York and London: Garland Publishing.

Nikolajeva, Maria.(1998). 'Exit children's literature?'The Lion and the Unicorn, 22(2): 221-236.

Oittinen, Riitta.(2000). Translating for Children. New York: Garland Science.

O'Connell, Eithne. (2006). 'Translating for children'. In Gillian Lathey (ed.), The

Translation of Children's Literature: A Reader,15-24. Clevedon, Buffalo, Toronto:

Multilingual Matters.

Piechurska-Kuciel, Ewa and ElżbietaSzymanska-Czaplak(Eds.) (2013), Language in Cognition and Affect. Berlin Heidelberg: Springer-Verlag.

Puurtinen,Tiina.(1995). Linguistic Acceptability in Translated Children's Literature.Joensuu: University of Joensuu.

Shavit, Zohar. (1986). Poetics of Children's Literature. Athens and London: The University of Georgia Press.

Stolze, Radegundis. (2003). 'Translating for children - world view or pedagogics'. Meta: Translators' Journal, 48 (1-2): 208-221.

Suleiman, Yasir. (2005) 'From the periphery to the centre of marginality: Towards a prolegomenon of translating children's literature into Arabic'. Journal of Intercultural Communication Studies, 14 (4): 77-91.

Toury, Gideon.(1995). Descriptive Translation Studies - And Beyond. Amsterdam \& Philadelphia: John Benjamins.

Yousef, Abdel.(1985). Kutub al-Atfal fi 'Alamina al-Mu'assir(Children's Books of Our Time). Cairo and Beirut: Dar Al-KitabAlmasri and Dar Al-kitabAllubnani.

Yousef, Tawfiq. (2002). 'Translation and the cultural dimension.A postcolonialpoststructuralist approach'.International Journal of Arabic-English Studies, 3: 105-118. 
Yousef, Tawfiq. (2019). 'Cultural identity in Monica Ali's Brick Lane: A Bhabhian perspective'. International Journal of Arabic-English Studies, 3: 71-86. Venuti, Lawrence. (1995). The Translator's Invisibility: A History of Translation. London \& New York: Routledge. 